\title{
HOW DID RAPID CREDIT GROWTH CAUSE NON-PERFORMING LOANS IN THE CEE COUNTRIES?
}

Blanka Skrabic Peric, Nikola Konjusak

\section{Abstract}

This paper investigates the influence of three types of credit growth on non-performing loans in eleven Central and Eastern European countries during the period from 1999 to 2013. As opposed to previous research on credit risk, we have moved the focus from the usually investigated bank-specific and macroeconomic variables to different types of credit growth from earlier periods. At the same time, the results of this research give answer on the studies before the crisis, which tried to determine the possible consequences of rapid credit growth in the CEE countries. The results indicate that at least two years are necessary for each type of credit growth to increase credit risk. Finally, empirical results confirm the importance of both bank-specific and macroeconomic variables.

\section{Keywords: Credit Growth, Non-Performing Loans, CEE countries, Dynamic Panel Data}

JEL classification: $G 21, G 32, C 23$

\section{INTRODUCTION}

Considering rapid credit growth in Central and Eastern European (CEE) countries before the crisis and more intensive increase of non-performing loans (NPLs) during the crisis in these countries in comparison to other European countries, motivated us to investigate the influence of rapid credit growth on credit risk in the CEE countries. Before the financial crisis, rapid credit growth in the CEE countries was a very intriguing research topic (Pazarbasioglu et al. 2005; Backé and Égert 2006; Backé et al. 2007). The stated authors concluded that rapid credit growth which is not followed by economic growth can cause macroeconomic and financial instability and endanger asset quality in the future.

However, at that time it was not possible to find empirical evidence on the relationship between credit growth and credit risk. The emergence of the crisis and rise of NPLs increased the interest for analyzing the determinants of credit risk in the CEE countries. Most of the research papers focus on macroeconomic and/or bank-specific determinants of NPLs (Cerutti et al. 2010; Jakubík and Reininger 2013; Klein 2013; Tanasković and Jandrić 2015) while credit growth is still not recognized as one of the key determinants. Several research studies considered certain indicators of credit growth as control variables but the results

Blanka Skrabic Peric, PhD

Assistant Professor

University of Split, Faculty of Economics

E-mail: bskrabic@efst.hr

\section{Nikola Konjusak}

University of Split, Faculty of Economics

E-mail: nikola.konjusak@gmail.com 
vary with the indicator used and with the number of lags as well.

However, the problem of rapid credit growth and bank system stability is not a problem which is specific only for the CEE countries, but it also exists in other developing and developed countries. To preserve the stability of the bank system, the Basel Committee on Banking Supervision (2010) provided guidance for national authorities on how to use a buffer of capital to protect the banking sector from periods of excess aggregate credit growth that had often been associated with the buildup of system-wide risk. They proposed the credit-to-GDP gap as a useful common reference point for taking buffer decisions. This document additionally motivates researchers to evaluate the countercyclical capital buffer proposal. On the one hand, Derhmannn and Gambarcorta (2012) in a simulation study confirmed that buffer decision by using the credit-to-GDP gap could help to reduce credit growth during the booms and attenuate the credit contraction once it is released. On the other hand, Repullo and Saurina (2011) critically assessed the countercyclical buffer, which is based on the credit-to-GDP gap indicator. They found weaknesses of the credit-to-GDP gap indicator and they proposed GDP growth as a more suitable indicator of capital buffer decisions.

Nevertheless, only a few papers have attempted to seriously investigate the relationship between the lagged value of credit growth and bank credit risk. Jiménez and Saurina (2006) found that four years were necessary for rapid credit growth to increase the level of NPLs in Spain while Foos et al. (2010) found that three years were necessary for abnormal loan growth to increase loan loss provisions in 16 developed countries. Their results give us an additional argument to determine which time period is necessary for credit growth to lead to an increase of NPLs in the CEE countries.

Considering the results of previous empirical research, this research includes micro and macro determinants of credit risk with a special focus on lagged credit growth as a cause of NPLs. Considering different indicators of credit growth used in previous research, this research considers three different types of credit growth which indicate different bank strategies. Hence, the central aim of this research is to give an answer to the following questions: How did rapid credit growth cause NPLs in the CEE countries? and how many years does it take for credit growth to influence NPLs? The recent financial crisis caused a strong increase of NPLs in the last few years which created an interesting economic situation and provided us with an opportunity to test the impact of rapid credit growth on credit risk in the CEE countries.
The research is based on a dynamic panel analysis of the macroeconomic data and bank level data from the Bankscope database for 237 banks from 11 CEE countries, EU members, for the period from 1999 to 2013.

This study contributes to previous research on credit risk in several ways. Firstly, the empirical literature on the relationship between rapid credit growth and credit risk is rare. Secondly, the research period includes a period of credit growth and a period of growth of NPLs that enables us to find the relationship between credit cycles and credit risk in the CEE countries. Thirdly, most of the related studies for the CEE countries analyzed the link the between economic cycles, loan growth and loan losses at the aggregate level. Our paper considers the relationship between rapid credit growth and credit risk on bank level. Additionally, the considered period provides an opportunity to get an empirical answer on possible consequences of rapid credit growth in the CEE countries that have been only theoretically considered before the crisis. Fourthly, the results provide robust evidence of a positive relationship between previous credit growth and NPLs. Precisely, it provides evidence that credit growth is reflected on NPLs in two years. Finally, this research considers three types of credit growth (bank's credit growth, bank's credit growth above the country average and bank's credit growth above the CEE region average) in order to make a conclusion as to what kind of credit growth affects the NPLs the most. The results indicate that all considered types of credit growth will influence on the increase of NPLs in the future.

The following section of the paper gives a short review of previous research on credit risk and the relationship between credit growth and NPLs in the CEE countries. Section 3 discusses the main methodological issues. Section 4 describes the empirical model and data used. Section 5 presents a review of the empirical results and Section 6 provides conclusions.

\section{LITERATURE REVIEW}

In the last two decades, the banking sector of the CEE countries has attracted the attention of many scholars. During the process of transition from planned to market-oriented economies that started in 1990, these countries went through many changes. The period was characterized by foreign capital inflow, foreign bank ownership, reforms of the banking system, and rapid credit growth.

Therefore, the main focus of previous research was banking system reform and development (Bonin 
and Schnabel 2011; Bonin et al. 2013), the role of foreign ownership in the CEE countries (Kraft 2002; de Haas and van Lelyveld 2006; Aydin 2008) and differences between foreign and domestic banks (Bonin et al. 2005; Degryse et al. 2012; Havrylchyk and Jurzyk 2011). Rapid credit growth in the CEE countries was also in the focus of some authors (Pazarbasioglu et al. 2005; Backé and Égert 2006; Backé et al. 2007). These authors concluded that rapid credit growth which is not followed by economic growth can cause macroeconomic and financial instability and endanger asset quality in the future. It was not possible to find empirical evidence about the relationship between credit growth and credit risk at that time. Therefore, researchers could only detect credit growth above equilibrium and try to predict possible consequences of rapid credit growth.

During the credit and economic growth in the CEE countries, credit risk was not the focus of scientific research. However, several papers analyzing credit risk in these countries were written during that period (Glogowski 2008; Agoraki et al. 2011). The emergence of the crisis and the rise of NPLs increased the interest for analyzing determinants of credit risk in developed and developing countries. However, most of the research papers still focused on macroeconomic determinants and/or bank-specific variables of NPLs (Cerutti et al. 2010; Jakubík and Reininger 2013; Klein 2013). The general conclusion of these papers is that various macroeconomic variables have a significant impact on rise of NPLs. The main determinant in all papers is GDP growth. Other macroeconomic determinants such as unemployment, interest rate, inflation and exchange rate also show a significant influence on the NPLs ratio. Some researchers found that bankspecific variables such as profitability, capital ratio and bank size also have a significant influence.

Considering the rapid credit growth before the crisis and the fact that the increase of NPLs was greater in the CEE than other European countries motivated us to investigate the influence of rapid credit growth on credit risk in the CEE countries. However, rapid credit growth is very rarely included in credit risk modeling in the CEE countries. Some recent research papers on credit risk in the CEE countries also include first or second lag of credit growth as control variables (Glogowski 2008; Škrabić Perić 2012; Jakubík and Reininger 2013; Klein 2013; Skarica 2014). The results changed the sign and statistical significance with regard to the indicator used and the number of lags. Additionally, most of the abovementioned studies, except Glogowski (2008) and Škrabić Perić (2012), used the indicator of credit growth on aggregate level (credit to GDP). This research tries to investigate the real influence of rapid credit growth on NPLs on the bank level by using three different indicators of credit growth.

\section{METHODOLOGY}

Considering previous research on credit risk, it is obvious that NPLs are an autoregressive process (Agoraki et al. 2011; Jakubík and Reininger 2013; Klein $2013, . .$.$) . Therefore, the lagged value of NPLs is includ-$ ed in the model.

For empirical analysis of NPLs, the following regression is used:

$$
\begin{aligned}
& n p l s_{i t}=\mu+\gamma n p l s_{i, t-1}+\beta_{1} x_{i t 1}+\beta_{2} x_{i t 2}+\ldots \\
& +\beta_{K} x_{i t K}+\alpha_{i}+\varepsilon_{i t}, i=1, \ldots, N, t=1, \ldots, T,
\end{aligned}
$$

where $N$ is the number of banks, $T$ is the number of periods, $n p l_{i t}$ is the value of the dependent variable of bank $i$ in the period $t$, the parameter $\mu$ is the constant, $n p l s_{i, t-1}$ is the lagged value of $n p l s_{i t}, x_{i t 1}, \ldots ., x_{i t K}$ are the independent variables and $K$ is the number of independent variables in the model while $\beta_{1}, \beta_{2}, \ldots, \beta_{K}$ are the parameters of exogenous variables and $\gamma$ is the parameter of lagged dependent variable. Finally, $\alpha_{i}$ is the time-invariant bank-specific effect (it can be alternatively specified to belong to an error term) and $\varepsilon_{i t}$ is the remaining part of the error term in the model. It is assumed that all variables $x_{i t}$ are uncorrelated with $\varepsilon_{i t}$. With inclusion of lagged dependent variable $n p l s_{i, t-1}$ in the model, it becomes correlated with $\alpha_{i}$. Due to the observed correlation, the most commonly used estimator for static panel data becomes a bias and is inconsistent. Therefore, specific estimators are derived for dynamic panel data. The most used estimators in research with a large $N$ and a small $T$ are the difference GMM estimator proposed by Arellano and Bond (1991) and the system GMM estimator proposed by Arellano and Bover (1995) and Blundell and Bond (1998). To overcome the correlation between $n p l s_{i, t-1}$ and $\alpha_{i}$, Arellano and Bond (1991) proposed taking equation (1) in first differences:

$$
\begin{aligned}
& n p l s_{i t}-n p l s_{i, t-1}=\gamma\left(n p l s_{i, t-1}-n p l s_{i, t-2}\right)+ \\
& +\beta_{1}\left(x_{i t 1}-x_{i, t-1,1}\right)+\beta_{2}\left(x_{i t 2}-x_{i, t-1,2}\right)+\ldots \\
& +\beta_{K}\left(x_{i t K}-x_{i, t-1, K}\right)+\left(\varepsilon_{i t}-\varepsilon_{i, t-1}\right) \\
& i=1, \ldots N, t=1, \ldots, T
\end{aligned}
$$

Although (2) $\alpha_{i}$ is excluded from the equation, the problem arises with $n p l s_{i, t-1}$ which is correlated with $\varepsilon_{i t-1 .}$. In order to solve this problem, instrumental 
variables are included in the model. Valid instruments for $\left(n p l s_{i, t-1}-n p l s_{i, t-2}\right)$ are lagged values of dependent variable in level $\left(n p l s_{i, t-2}, \ldots, n p l s_{i 2}, n p l s_{i 1}\right)$. Further, if some of $x_{i t k}, k=1,2, \ldots, K$ is endogenous in the sense that $E\left(x_{i t k} \varepsilon_{i s}\right)=0$ for $s>t$ and $E\left(x_{i t k} \varepsilon_{i s}\right) \neq 0$ otherwise, lagged values of independent variable $\left(x_{i t-2, k}, \ldots, x_{i 2 k}, x_{i 1 k}\right)$ are valid instruments for $\left(x_{i t k}-x_{i, t-1, k}\right)$. Thus, this estimator outperforms previous estimators in terms of bias, but it shows weaknesses when the dependent variable is highly persistent and in the case when the ratio of the individual effect variance and the remained error variance increases. However, the system GMM, except the equation in first differences (2), uses equation in levels (1). To avoid the problem of correlation between $n p l s_{i, t-1}$ and $\alpha_{i}$ in equation (1), instrumental variables are introduced. The valid instrument for lagged dependent variable $n p l s_{i, t-1}$ in equation (1) is lagged value of dependent variable in first differences $\Delta n p l s_{i, t-1}$. Also, in the case of endogenous independent variable $x_{i t k}, k=1,2, \ldots, K, \Delta x_{i, t-1, k}$ is a valid instrument for this variable. This estimator shows better properties than the difference GMM estimator and all other estimators in numerous studies (Blundell and Bond, 2000; Bond $2002, \ldots .$.$) . The two-step system GMM estimator$ is applied here because it relaxes the assumption of error term independency and, moreover, it is robust to heteroscedasticity and it is more efficient than the one-step estimator. However, standard errors of the two-step estimator underestimate the standard error in small samples but Windmeijer (2005) corrected the formula for the two-step variance and made it concurrent to the one-step estimator.

\section{EMPIRICAL MODEL AND DATA}

Considering the results of previous research, the basic model of NPLs consists of the main determinants of bank-specific and main macroeconomic indicators:

$$
\begin{aligned}
& \text { npls }_{i t}=\mu+\gamma \text { npls }_{i, t-1}+\beta_{1} \text { roa }_{i t}+ \\
& +\beta_{2} \text { ltotalassets }_{i t}+\beta_{3} \text { inflation }_{i t}+ \\
& +\beta_{4} \text { gdpg }_{i t}+\beta_{5} \text { rirr }_{i t}+\alpha_{i}+\varepsilon_{i t} \\
& i=1, \ldots, N, t=1, \ldots, T
\end{aligned}
$$

where dependent variable $n p l s_{i t}$ is a share of NPLs in total loans for bank $i$ in year $t, n p l_{i, t-1}$ is a lagged value of dependent variable, roa $_{i t}$ is an indicator of profitability for bank $i$ in year $t_{\text {, }}$ totalassets $i t$ is an indicator of the size of bank $i$ in year $t$, inflation $i t$ is the percentage of price change in the country of the bank $i$ in year $t$, $g d p g_{i t}$ is the GDP growth in the country of the bank $i$ in year $t$, rirr $_{i t}$ is the real interest rate in the country of the bank $i$ in year $t, \mu$ is a constant term, $\alpha_{i}$ is a specific error for each bank and $\varepsilon_{i t}$ is the remain part of error, $\gamma$, $\beta_{1}, \ldots, \beta_{5}$ are parameters to estimate.

Data has been obtained from the Bankscope database and covers the period from 1999 to 2013 ( $T=15$ ) for $N=237$ banks from eleven CEE countries which are members of the European Union: Bulgaria, Croatia, the Czech Republic, Estonia, Hungary, Latvia, Lithuania, Poland, Romania, Slovakia, and Slovenia. The research includes 4 types of banks: bank holdings, commercial banks, cooperative banks, and savings banks. All macroeconomic variables are obtained from the World Bank Database.

The first group of variables is a group of bank-specific variables. The dependent variable is non-performing loans in total loans ratio ( $n p / s)$ and it is expected that the lagged values of NPLs will have a statistically significant positive influence on NPLs today. The same influence was found in similar studies (Jiménez and Saurina 2006; Škrabić Perić 2012; Jakubík and Reininger 2013).

The first bank-specific independent variable is return on average assets (roa) and it is expected that the increase in ROA will have a statistically significant negative influence on NPLs because a higher profitability results in a lower rate of NPLs. Moreover, many authors have emphasized this highly negative connection between ROA and NPLs.

The second bank-specific variable is logarithm of banks' total assets (ltotassets) and it is expected that the value of total assets will have a positive or negative influence on NPLs. On the one hand, it is expected that greater assets bring a greater responsibility for managers and that way greater assets decreases the bank's risk taking. Additionally, big banks usually have corporate governance and a better quality system, therefore, negative relation can be expected. On the other hand, large banks can increase their risk because of "too big to fail" presumption.

The second group of variables is a group of macroeconomic variables that includes three indicators. Gross domestic product growth ( $g d p g$ ) is measured as a percentage. The expected sign is negative because a better economic situation would increase the creditworthiness of borrowers and facilitate loan repayment. In most empirical papers, GDP growth is proven as the most important determinant of NPLs.

The second macroeconomic variable is inflation. $A$ percentage change of general price increase (inflation) is the measure of inflation. Inflation can have a positive or negative influence. In some cases, inflation can have a negative influence on NPLs because it reduces the loan's real value and makes repayment easier or, based on the Philip curve, inflation can decrease 
unemployment and increase creditworthiness of borrowers. However, more often, it has a positive sign which indicates that because of 'sticky wages' inflation diminishes the real value of wages (Klein 2013; Skarica 2014).

The third macroeconomic determinant is the interest rate measured by real interest rate (rirr). The expected sign for interest rate is positive because an increase in interest rate decreases the borrower's ability to repay debt. In most previous research, the interest rate has shown a positive sign.

To investigate the relationship between credit growth and NPLs, the model of credit risk is extended by previous values of credit growth:

$$
\begin{aligned}
& n p s_{i t}=\mu+\gamma n p s_{i, t-1}+\beta_{1} \text { roa }_{i t}+ \\
& +\beta_{2} \text { ltotalassets }_{i t}+\beta_{3} \text { inflation }_{i t}+ \\
& +\beta_{4} \text { gdpg }_{i t}+\beta_{5} \text { rirr }_{i t}+\sum_{k=1}^{p} \beta_{5+k} \text { gloans }_{i, t-k}+ \\
& +\alpha_{i}+\varepsilon_{i t} ; i=1, \ldots, N, t=1, \ldots, T
\end{aligned}
$$

where gloans $_{i, t-k}$ is an indicator of credit growth for bank $i$ in year $t-k, p$ is the maximum number of previous years which are being considered.

The basic model of credit risk is upgraded by previous values of credit growth. Three different types of credit growth indicators are considered. The first indicator is bank's total loans growth (gloans) in percentage.

The second indicator of credit growth is the difference between a bank's loan growth in year $t$ and average loan growth in the whole country in the year $t$ (lcounaverage). This indicator refers to the bank's credit growth in comparison to the country average. The significance of this indicator suggests that banks with credit growth above industry average have a higher portfolio risk. Namely, to achieve above average credit growth, banks have to attract new clients by offering better conditions (lower interest rate) or accepting less transparent clients. The second scenario increases NPLs in the future.

Finally, the third indicator is the difference between a bank's loan growth in year $t$ and average loan growth in the whole CEE region in the year $t$ (lregaverage). This indicator is introduced because most foreign banks in the CEE countries are a part of a multinational bank holding and all credit policies are designed in the head office for all subsidiaries considering the situation in the whole CEE region. This indicator can, therefore, show whether this group's credit policy is a cause of credit risk in CEE banks because country specifics are neglected.

Different credit growth indicators have been chosen in order to determine what kind of credit growth influences NPLs the most and how fast it is manifested. Also, using different indicators of credit growth contributes to the robustness of the relationship between NPLs and credit growth.

Descriptive statistics of all variables and their mean values, minimum and maximum values, standard deviations and number of observations are presented in Table1.

In the correlation matrix in Table 2, it is evident that the correlation coefficient between NPLs and other independent variables except credit growth have the expected signs. Correlation between gloans and $\mathrm{npls}$ is negative. Its relation is not totally unexpected because it is not possible that credit growth endangers credit quality in the same year. Our assumptions is that several years are necessary for credit growth to influence the growth of NPLs.

Considering coefficients between independent variables, it can be concluded that the problem of multicollinearity can arise because of the correlation between gdpg and rirr. Therefore, greater attention will be given to these two variables in the empirical part.

Table 1: Descriptive statistics of all variables

\begin{tabular}{|l|c|r|r|r|r|}
\hline Variable & Obs & Mean & Std. Dev. & Min & 0 \\
\hline npls (\%) & 1219 & 11.30948 & 13.02354 & 96.24 \\
\hline roa (\%) & 1219 & 0.446669 & 2.639641 & -29.28 & 18.41 \\
\hline totassets (million USD) & 1219 & 5107.661 & 8464.637 & 11.13 & 52017.19 \\
\hline gdpg (\%) & 1219 & 2.284307 & 4.748597 & -14.81 & 11.62 \\
\hline inflation (\%) & 1219 & 4.602264 & 5.055068 & -1.22 & 45.8 \\
\hline rirr (\%) & 1219 & 5.229902 & 4.437748 & -7.21 & 29.36 \\
\hline gloans (\%) & 1162 & 18.82279 & 37.54952 & -67.28 & 602.65 \\
\hline Icounaverage (percentage point) & 1162 & -3.6187 & 34.50223 & -139.14 & 537.61 \\
\hline Iregaverage (percentage point) & 1162 & -5.46248 & 35.07209 & -98.16 & 565.24 \\
\hline
\end{tabular}


Table 2: Correlation matrix of dependent and independent variables

\begin{tabular}{|l|l|l|l|l|l|l|l|}
\hline \multicolumn{3}{|c|}{ npls } & roa & ltotassets & inflation & gdpg & \\
\hline npls & 1.0000 & & & & & \\
\hline roa & -0.4391 & 1.0000 & & & & \\
\hline Itotassets & -0.2150 & 0.2153 & 1.0000 & & & \\
\hline inflation & -0.1429 & 0.0536 & -0.1085 & 1.0000 & & \\
\hline gdpg & -0.2363 & 0.2350 & -0.0380 & 0.1285 & 1.0000 & & \\
\hline rirr & 0.2185 & -0.2088 & -0.0863 & -0.1344 & -0.6148 & 1.0000 & \\
\hline gloans & -0.2689 & 0.0202 & -0.1369 & 0.1855 & 0.3301 & -0.2352 & 1.0000 \\
\hline
\end{tabular}

Table 3: Correlation matrix between three different credit growth indicators

\begin{tabular}{|l|c|c|c|}
\hline & gloans & Icounaverage & Iregaverage \\
\hline gloans & 1.0000 & & \\
\hline Icounaverage & 0.8494 & 1.0000 & \\
\hline Iregaverage & 0.9390 & 0.9023 & 1.0000 \\
\hline
\end{tabular}

The correlation matrix in Table 3 shows very strong positive correlation levels between the three credit growth indicators. In that sense, it is expected that all credit growth indicators will have a similar impact on NPLs and they will be included separately in different specifications of the model to prevent the problem of multicollinearity.

\section{EMPIRICAL RESULTS}

To look for evidence on relationship between previous values of credit growth and credit risk, nine different specifications of the model of credit risk are estimated using the two-step system GMM estimator with a robust standard error. To avoid the problem of too many instruments for a dependent variable, a maximum of two lags is used as the instrument. There is convincing evidence that too many instrument conditions introduce bias while increasing efficiency. Simply by being numerous, instruments can overfit instrumented variables (Roodman 2009). Additional instruments for independent variables are introduced only if the result of the Sargan test indicates a problem of endogeneity in the model. The Sargan test has the null hypothesis that the instrumental variables are uncorrelated with the residuals. The results of the empirical part of the research are presented in Table 4 and Table 5.

All model specifications from Table 4 and Table 5 except Model(3) passed the Sargan test which means there is no problem of endogeneity in all the specified models except in Model(3). Additional instrument variables are introduced but the result of the Sargan test did not change. Also, in all specifications there is no second order autocorrelations between the difference residuals. The $p$ value of all $A R(2)$ tests is above 0.05 .

Model(1), Model(2) and Model(6) are different specifications of the basic model. When Model(1) was upgraded with additional variables, a lot of variables became statistically insignificant or changed the sign. That can be a consequence of multicollinearity between the interest rate and GDP growth. A potential problem is indicated by the value correlation coefficient in Table 2. Therefore, two different versions of basic models are considered. In Model(2)-Model(5) the variable rirr is omitted while in Model(6)-Model(9) the variable $g d p g$ is omitted.

The results from Table 4 and Table 5 indicate that the lagged value of NPLs is, as expected, positive and statistically significant. The results indicate a high persistence of NPLs in the CEE countries. Therefore, roa has a negative and statistically significant influence, gdpg a negative and statistically significant influence, rirr a positive and statistically significant influence while bank's size and inflation are not statistically significant.

Based on our research findings, roa has a negative and statistically significant influence on dependent variable in all specifications of the model. This result was expected because it corresponds with economic theory and earlier empirical findings (Jiménez and Saurina 2006; Škrabić Perić 2012).

The second bank-specific variable is ltotassets which turned out to be statistically insignificant in all specifications of the model. These results can be explained with the fact that several big banks dominate in most of the CEE countries. Therefore, big banks increase credit risk to additionally increase market share. On the other hand, smaller banks are forced to accept riskier business in order to survive. Additionally, these results are in line with Škrabić Perić (2012).

The most important macroeconomic variable in our model is $g d p g$ and the results indicate that it has 
Table 4: Results of models of NPLs and credit growth (1-5)

\begin{tabular}{|c|c|c|c|c|c|}
\hline Variable & Model (1) & Model (2) & Model (3) & Model (4) & Model (5) \\
\hline \multirow[t]{2}{*}{ L.npls } & $0.858^{* * *}$ & $0.818^{* * *}$ & $0.807^{* * *}$ & $0.805^{* * *}$ & $0.798^{* * *}$ \\
\hline & $(0.0421)^{a}$ & $(0.0978)$ & $(0.138)$ & $(0.102)$ & $(0.112)$ \\
\hline \multirow[t]{2}{*}{ roa } & $-1.174^{* * *}$ & $-1.054^{* * *}$ & $-1.488^{* * *}$ & $-1.508^{* * *}$ & $-1.540^{* * *}$ \\
\hline & $(0.284)$ & $(0.239)$ & $(0.325)$ & $(0.274)$ & $(0.293)$ \\
\hline \multirow[t]{2}{*}{ Itotassets } & 0.498 & 0.347 & 0.904 & 0.187 & 0.353 \\
\hline & $(1.466)$ & $(1.431)$ & $(1.669)$ & $(1.713)$ & $(1.851)$ \\
\hline \multirow[t]{2}{*}{ inflation } & 0.0116 & -0.00765 & 0.00367 & 0.0514 & 0.00300 \\
\hline & $(0.0757)$ & $(0.0877)$ & $(0.0960)$ & $(0.0918)$ & $(0.0947)$ \\
\hline \multirow[t]{2}{*}{ gdpg } & $-0.102^{* *}$ & $-0.157^{* * *}$ & -0.0824 & $-0.106^{* *}$ & $-0.102^{*}$ \\
\hline & $(0.0501)$ & $(0.0486)$ & $(0.0587)$ & $(0.0532)$ & $(0.0577)$ \\
\hline \multirow[t]{2}{*}{ rirr } & $0.141^{* *}$ & & & & \\
\hline & $(0.0687)$ & & & & \\
\hline \multirow[t]{2}{*}{ L.gloans } & & & 0.00768 & & \\
\hline & & & $(0.00933)$ & & \\
\hline \multirow[t]{2}{*}{ L2.gloans } & & & $0.0209^{* *}$ & & \\
\hline & & & $(0.00911)$ & & \\
\hline \multirow[t]{2}{*}{ L3.gloans } & & & 0.0125 & & \\
\hline & & & $(0.00799)$ & & \\
\hline \multirow{2}{*}{ L.Icounaverage } & & & & 0.0185 & \\
\hline & & & & $(0.0129)$ & \\
\hline \multirow[t]{2}{*}{ L2.Icounaverage } & & & & $0.0228^{* *}$ & \\
\hline & & & & $(0.0101)$ & \\
\hline \multirow[t]{2}{*}{ L3.Icounaverage } & & & & 0.00669 & \\
\hline & & & & $(0.0102)$ & \\
\hline \multirow[t]{2}{*}{ L.Iregaverage } & & & & & 0.0187 \\
\hline & & & & & $(0.0120)$ \\
\hline \multirow[t]{2}{*}{ L2.Iregaverage } & & & & & $0.0230^{*}$ \\
\hline & & & & & $(0.0122)$ \\
\hline \multirow[t]{2}{*}{ L3.Iregaverage } & & & & & 0.0110 \\
\hline & & & & & $(0.0106)$ \\
\hline \multirow[t]{2}{*}{ _cons } & 0.814 & 2.360 & -0.108 & 3.436 & 3.109 \\
\hline & $(5.035)$ & $(5.223)$ & (6.612) & (6.492) & $(6.970)$ \\
\hline $\mathrm{N}$ & 958 & 1252 & 965 & 965 & 965 \\
\hline Sargan & 0.1246 & 0.0405 & 0.0354 & 0.0899 & 0.0965 \\
\hline $\operatorname{AR}(2)$ & 0.4977 & 0.8703 & 0.9937 & 0.9081 & 0.9620 \\
\hline
\end{tabular}

aStandard errors in parentheses, ${ }^{*} p<0.1,{ }^{* *} p<0.05,{ }^{* * *} p<0.01$

a negative sign and statistical significance in different specifications. However, $g d p g$ is economically and theoretically an important determinant of NPLs in all previous empirical studies. Another macroeconomic indicator rirr was included in model specifications, i.e. Model(6)-Model(9) and the results showed a positive influence and strong statistical significance.

In contrast with previous research on credit risk, inflation is not statistically significant. Similar results were obtained from a recent paper by Tanasković and Jandrić (2015). In the last several years, NPLs in the CEE countries has increased rapidly while all these countries have kept the inflation stable (lossifov and Podpiera 2014). Considering this fact, the result of non-significant inflation is not totally unexpected.

In Model(3)-(5) and Model(7)-(9), lagged values of different types of credit growth are included. In order to avoid introduction of too many lags, considering the previous results and short time span, first, second and third lags are included in all specifications.

From the results, it is clear that all types of credit growth are dangerous. All used indicators of credit growth have similar values. Hence, two-year lagged credit growth has a positive influence on the 
Table 5: Results of models of NPLs and credit growth (6-9)

\begin{tabular}{|c|c|c|c|c|}
\hline Variable & Model (6) & Model (7) & Model (8) & Model (9) \\
\hline \multirow[t]{2}{*}{ L.npls } & $0.857^{* * *}$ & $0.923 * * *$ & $0.867^{* * *}$ & $0.859^{* * *}$ \\
\hline & $(0.0428)^{a}$ & $(0.0792)$ & $(0.0641)$ & $(0.0605)$ \\
\hline \multirow[t]{2}{*}{ roa } & $-1.229^{* * *}$ & $-1.550^{* * *}$ & $-1.488^{* * *}$ & $-1.580^{* * *}$ \\
\hline & $(0.272)$ & $(0.342)$ & $(0.295)$ & $(0.309)$ \\
\hline \multirow[t]{2}{*}{ Itotassets } & 0.826 & -0.000932 & -0.531 & -0.513 \\
\hline & $(1.420)$ & (1.905) & $(1.928)$ & (2.007) \\
\hline \multirow[t]{2}{*}{ inflation } & 0.0187 & -0.0232 & 0.0674 & 0.0119 \\
\hline & $(0.0810)$ & (0.101) & $(0.0873)$ & $(0.0927)$ \\
\hline \multirow[t]{2}{*}{ rirr } & $0.186^{* * *}$ & $0.125^{*}$ & $0.157^{* *}$ & $0.161^{* *}$ \\
\hline & $(0.0638)$ & $(0.0752)$ & $(0.0788)$ & $(0.0791)$ \\
\hline \multirow[t]{2}{*}{ L.gloans } & & 0.0179 & & \\
\hline & & $(0.0201)$ & & \\
\hline \multirow[t]{2}{*}{ L2.gloans } & & $0.0336^{* *}$ & & \\
\hline & & $(0.0162)$ & & \\
\hline \multirow[t]{2}{*}{ L3.gloans } & & 0.00795 & & \\
\hline & & $(0.0118)$ & & \\
\hline \multirow{2}{*}{ L.Icounaverage } & & & 0.0244 & \\
\hline & & & $(0.0195)$ & \\
\hline \multirow{2}{*}{ L2.Icounaverage } & & & $0.0218^{*}$ & \\
\hline & & & $(0.0124)$ & \\
\hline \multirow[t]{2}{*}{ L3.Icounaverage } & & & -0.00569 & \\
\hline & & & $(0.0107)$ & \\
\hline \multirow{2}{*}{ L.Iregaverage } & & & & 0.0275 \\
\hline & & & & $(0.0190)$ \\
\hline \multirow[t]{2}{*}{ L2.Iregaverage } & & & & $0.0253^{*}$ \\
\hline & & & & $(0.0131)$ \\
\hline \multirow[t]{2}{*}{ L3.Iregaverage } & & & & 0.00415 \\
\hline & & & & $(0.0102)$ \\
\hline \multirow[t]{2}{*}{ _cons } & -0.662 & 1.258 & 4.534 & 4.946 \\
\hline & $(4.845)$ & $(6.896)$ & $(6.948)$ & $(7.101)$ \\
\hline $\mathrm{N}$ & 958 & 736 & 736 & 736 \\
\hline Sargan & 0.1576 & 0.1877 & 0.2740 & 0.2449 \\
\hline $\operatorname{AR}(2)$ & 0.4787 & 0.6756 & 0.7414 & 0.6784 \\
\hline
\end{tabular}

aStandard errors in parentheses, ${ }^{*} p<0.1,{ }^{* *} p<0.05,{ }^{* * *} p<0.01$

occurrence of NPLs in the CEE countries. Finally, the bank's credit growth above credit growth in the CEE region is the least dangerous one. It is statistically significant at the level of $10 \%$ in Model(5) and Model(9). Therefore, credit policy on a regional base does not additionally increase the credit risk of banks in the CEE countries.

The results indicate that credit growth in the CEE countries influences NPLs somewhat faster than in developed countries i.e. four years in Spain (Jiménez and Saurina 2006) and three years in developed economies (Foos et al. 2010). However, these results are in line with Jakubík and Reininger (2013) who used quarterly data and found that the sixth lag of credit to GDP influence increases NPLs on the aggregate level.

As additional robustness check, all model specifications are estimated by using Least Squares Dummy Variables corrected estimator proposed by Kiviet (1995). Namely, Kiviet (1995) upgraded fixed effects estimator by removing bias from estimation. This estimator showed good properties in simulation studies (Kiviet 1995; Judson and Owen 1999,...). The results are presented in Table $A 1$ and Table $A 2$ in the Appendix. The results additionally confirm the findings in Table 4 and Table 5. 


\section{CONCLUSION}

This paper investigates the influence of bank-specific variables, macroeconomic variables and credit growth indicators on NPLs in eleven CEE countries in the period 1999-2013. The results of all bank-specific and macroeconomic variables are almost in line with previous research on credit risk. ROA has a negative and statistically significant influence on NPLs, while the size is not statistically significant. GDP growth and interest rate are significant macroeconomic variables. GDP growth has a negative influence on NPLs. Inflation is not statistically significant. This paper contributes to previous research by considering theoretical implications of credit growth on the increase of NPLs and by introducing different indicators of credit growth in the empirical model of credit risk. In that sense, the focus from the usually investigated variables has been moved to earlier values of credit growth when the problem actually occurred. Our research has shown that two years are necessary for credit growth to influence the growth of NPLs for all types of credit growth.

Therefore, based on the results of our research, several important policy implications have emerged. Firstly, supervisors should pay much more attention to the possibility that credit risk can also increase during the upturns in the economy. This phenomenon can be controlled by introducing the previous value of credit growth of the bank in the credit risk model. Also, credit risk models have to be detected by banks that have credit growth above the country average in an observed year. Supervisors have to monitor those banks more strictly by requiring additional loan loss provisions or limiting their lending.

Lastly, our suggestion for further research is to estimate a similar model with credit by industry sector specifications and credit by currency specifications. Unfortunately, the above mentioned data are not available in the Bankscope database.

\section{REFERENCES}

Agoraki, M.-E. K., Delis, M. D. and Pasiouras, F. 2011. Regulations, competition and bank risk-taking in transition countries. Journal of Financial Stability 7 (1): 38-48.

Arellano, M. and Bond, S. 1991. Some Tests of Specification for Panel Data: Monte Carlo Evidence and an Application to Employment Equations. The Review of Economic Studies 58 (2): 277-297.

Arellano, M. and Bover, O. 1995. Another look at the instrumental variable estimation of error-components models. Journal of Econometrics 68 (1): 29-51.
Aydin, B. 2008. Banking Structure and Credit Growth in Central and Eastern European Countries. International Monetary Fund. IMF Working Paper No. 08/215.

Backé, P. and Égert, B. 2006. Credit Growth in Central and Eastern Europe: New (Over)Shooting Stars? Focus on European Economic Integration (1): 112-139.

Backé, P., Égert, B. and Walko, Z. 2007. Credit Growth in Central and Eastern Europe Revisited. Focus on European Economic Integration (2): 69-77.

Basel Committee on Banking Supervision (2010). Guidance for national authorities operating the countercyclical capital buffer. Bank for International Settlements: Basel.

Blundell, R. and Bond, S. 1998. Initial conditions and moment restrictions in dynamic panel data models. Journal of Econometrics 87 (1): 115-143.

Blundell, R. and Bond, S. 2000. GMM Estimation with persistent panel data: an application to production functions. Econometric Reviews 19 (3): 321-340.

Bond, S. R. 2002. Dynamic panel data models: a guide to micro data methods and practice. Portuguese Economic Journal 1 (2): 141-162.

Bonin, J., Hasan, I. and Wachtel, P. 2013. Banking in transition countries. Wesleyan University. Wesleyan Economic Working Papers No. 2013-008.

Bonin, J. P. and Schnabel, I. 2011. The great transformation: From government-owned to foreign-controlled banking sectors. Economics of Transition 19 (3): 397-405.

Bonin, J. P., Hasan, I. and Wachtel, P. 2005. Privatization matters: Bank efficiency in transition countries. Journal of Banking \& Finance 29 (8-9): 2155-2178.

Cerutti, E., llyina, A., Makarova, Y. and Schmieder, C. 2010. Bankers Without Borders? Implications of Ring-Fencing for European Cross-Border Banks. International Monetary Fund, IMF Working Paper No. 10/247.

Degryse, H. A., Havrylchyk, O., Jurzyk, E. and Kozak, S. 2012. Foreign Bank Entry and Credit Allocation in Emerging Markets. Journal of Banking \& Finance 36 (11): 2949-2940.

Drehmann, M., and Gambacorta, L. 2012. The effects of countercyclical capital buffers on bank lending. Applied economics letters 19 (7): 603-608.

Foos, D., Norden, L. and Weber, M. 2010. Loan growth and riskiness of banks. Journal of Banking \& Finance 34 (12): 2929-2940.

Glogowski, A. 2008. Macroeconomic Determinants of Polish Banks' Loan Losses - Results of a Panel Data Study. National Bank of Poland, Working paper No. 53.

de Haas, R. and van Lelyveld, I. 2006. Foreign banks and credit stability in Central and Eastern Europe. A panel data analysis. Journal of Banking \& Finance 30 (7): 1927-1952.

Havrylchyk, O. and Jurzyk, E. 2011. Inherited or earned? Performance of foreign banks in Central and Eastern Europe. Journal of Banking \& Finance 35 (5): 1291-1302. 
lossifov, P. and Podpiera, J. 2014. Are Non-Euro Area EU Countries Importing Low Inflation from the Euro Area? International Monetary Fund. IMF Working Paper No.14/191.

Jakubík, P. and Reininger, T. 2013. Determinants of Nonperforming Loans in Central, Eastern and Southeastern Europe. Focus on European Economic Integration (3): 48-66.

Jiménez, G. and Saurina, J. 2006. Credit Cycles, Credit Risk, and Prudential Regulation. International Journal of Central Banking (IJCB) 2: 65-98.

Judson, R. A., and Owen, A. L. 1999. Estimating dynamic panel data models: a guide for macroeconomists. Economics Letters 65(1): 9-15.

Kiviet, J. F. 1995. On bias, inconsistency, and efficiency of various estimators in dynamic panel data models. Journal of Econometrics 68(1): 53-78.

Klein, N. 2013. Non-Performing Loans in CESEE: Determinants and Impact on Macroeconomic Performance. International Monetary Fund. IMF Working Paper No.13/72.

Kraft, E. 2002. Foreign banks in Croatia: Another look. Croatian National Bank: Zagreb.

Pazarbasioglu, C., Johnsen, G., Hilbers, M. P. L. C. and Ötker, M. I. 2005. Assessing and Managing Rapid Credit Growth and the Role of Supervisory and Prudential Policies. International Monetary Fund. Working Paper No.05/151.

Repullo, R. and Saurina, J. 2011. The countercyclical capital buffer of Basel III: A critical assessment, mimeo, CEMFI. Working Paper No. 1102.

Roodman, D. 2009. A Note on the Theme of Too Many Instruments. Oxford Bulletin of Economics and Statistics 71 (1): 135-158.

Saurina, J. and Jiménez, G. 2006. Credit Cycles, Credit Risk, and Prudential Regulation. International Journal of Central Banking 2(2):65-98.

Skarica, B. 2014. Determinants of non-performing loans in Central and Eastern European countries. Financial Theory and Practice 38 (1): 37-59.

Škrabić Perić, B. 2012. The impact of foreign ownership of bank on bank credit risk in the countries of Central and Eastern Europe: a dynamic panel models. Faculty of Economics, University of Split

Tanasković, S. and Jandrić, M. 2015. Macroeconomic and Institutional Determinants of Non-Performing Loans. Journal of Central Banking Theory and Practice 4 (1):47-62.

Windmeijer, F. 2005. A finite sample correction for the variance of linear efficient two-step GMM estimators. Journal of Econometrics 126 (1): 25-51. 
Table A1: Results of models of NPLs and credit growth (A1-A5) - LSDVc estimator

\begin{tabular}{|c|c|c|c|c|c|}
\hline Variable & Model (A1) & Model (A2) & Model (A3) & Model (A4) & Model (A5) \\
\hline \multirow[t]{2}{*}{ L.npls } & $0.807^{* * *}$ & $0.756^{* * *}$ & $0.702^{* * *}$ & $0.705^{* * *}$ & $0.711^{* * *}$ \\
\hline & $(0.0354)^{a}$ & $(0.0264)$ & $(0.0229)$ & $(0.0257)$ & $(0.0247)$ \\
\hline \multirow[t]{2}{*}{ roa } & $-0.845^{* * *}$ & $-0.996^{* * *}$ & $-1.375^{* * *}$ & $-1.352^{* * *}$ & $-1.348^{* * *}$ \\
\hline & $(0.169)$ & $(0.115)$ & $(0.149)$ & $(0.147)$ & $(0.149)$ \\
\hline \multirow[t]{2}{*}{ Itotassets } & 2.307 & $1.922^{*}$ & 1.302 & 0.888 & 0.686 \\
\hline & $(1.735)$ & $(1.162)$ & $(1.250)$ & $(1.251)$ & $(1.275)$ \\
\hline \multirow[t]{2}{*}{ inflation } & -0.106 & $-0.139^{*}$ & $-0.156^{*}$ & -0.121 & $-0.188^{* *}$ \\
\hline & $(0.0797)$ & $(0.0795)$ & $(0.0837)$ & $(0.0817)$ & $(0.0876)$ \\
\hline \multirow[t]{2}{*}{ gdpg } & $-0.193^{* * *}$ & $-0.252^{* * *}$ & $-0.184^{* * *}$ & $-0.219^{* * *}$ & $-0.208^{* * *}$ \\
\hline & $(0.0742)$ & $(0.0540)$ & $(0.0494)$ & $(0.0463)$ & $(0.0478)$ \\
\hline \multirow[t]{2}{*}{ rirr } & $0.120^{*}$ & & & & \\
\hline & $(0.0672)$ & & & & \\
\hline \multirow[t]{2}{*}{ L.gloans } & & & -0.00911 & & \\
\hline & & & $(0.00837)$ & & \\
\hline \multirow[t]{2}{*}{ L2.gloans } & & & $0.0111^{*}$ & & \\
\hline & & & $(0.00622)$ & & \\
\hline \multirow[t]{2}{*}{ L3.gloans } & & & $0.0113^{*}$ & & \\
\hline & & & $(0.00611)$ & & \\
\hline \multirow[t]{2}{*}{ L.Icounaverage } & & & & 0.00593 & \\
\hline & & & & $(0.00895)$ & \\
\hline \multirow[t]{2}{*}{ L2.Icounaverage } & & & & $0.0186^{* * *}$ & \\
\hline & & & & $(0.00527)$ & \\
\hline \multirow[t]{2}{*}{ L3.Icounaverage } & & & & $0.0146^{*}$ & \\
\hline & & & & $(0.00811)$ & \\
\hline \multirow[t]{2}{*}{ L.Iregaverage } & & & & & 0.00628 \\
\hline & & & & & $(0.00817)$ \\
\hline \multirow[t]{2}{*}{ L2.Iregaverage } & & & & & $0.0212^{* * *}$ \\
\hline & & & & & $(0.00649)$ \\
\hline \multirow[t]{2}{*}{ L3.Iregaverage } & & & & & $0.0128^{*}$ \\
\hline & & & & & $(0.00657)$ \\
\hline $\mathrm{N}$ & 956 & 1250 & 963 & 963 & 963 \\
\hline $\mathrm{R} 2$ & & & & & \\
\hline
\end{tabular}

aStandard errors in parentheses, ${ }^{*} p<0.1,{ }^{* *} p<0.05,{ }^{* * *} p<0.01$ 
Table A2: Results of models of NPLs and credit growth (A6-A9) - LSDVc estimator

\begin{tabular}{|c|c|c|c|c|}
\hline Variable & Model (A6) & Model (A7) & Model (A8) & Model (A9) \\
\hline \multirow[t]{2}{*}{ L.npls } & $0.811^{* * *}$ & $0.743^{* * *}$ & $0.738^{* * *}$ & $0.746^{* * *}$ \\
\hline & $(0.0345)^{a}$ & $(0.0385)$ & $(0.0374)$ & $(0.0377)$ \\
\hline \multirow[t]{2}{*}{ roa } & $-0.902^{* * *}$ & $-1.365^{* * *}$ & $-1.367^{* * *}$ & $-1.364^{* * *}$ \\
\hline & $(0.163)$ & $(0.161)$ & $(0.162)$ & $(0.159)$ \\
\hline \multirow[t]{2}{*}{ Itotassets } & $3.264^{* *}$ & $3.118^{*}$ & $3.088^{*}$ & $2.823^{*}$ \\
\hline & $(1.654)$ & $(1.723)$ & $(1.674)$ & $(1.708)$ \\
\hline \multirow[t]{2}{*}{ inflation } & -0.0853 & -0.0804 & -0.0525 & -0.120 \\
\hline & $(0.0825)$ & $(0.0887)$ & $(0.0853)$ & $(0.0850)$ \\
\hline \multirow[t]{2}{*}{ rirr } & $0.252^{* * *}$ & $0.166^{* * *}$ & $0.206^{* * *}$ & $0.205^{* * *}$ \\
\hline & $(0.0683)$ & $(0.0611)$ & $(0.0597)$ & $(0.0608)$ \\
\hline \multirow[t]{2}{*}{ L.gloans } & & $-0.0189^{*}$ & & \\
\hline & & $(0.00968)$ & & \\
\hline \multirow[t]{2}{*}{ L2.gloans } & & $0.0297^{* * *}$ & & \\
\hline & & $(0.00901)$ & & \\
\hline \multirow[t]{2}{*}{ L3.gloans } & & 0.00245 & & \\
\hline & & $(0.00925)$ & & \\
\hline \multirow[t]{2}{*}{ L.Icounaverage } & & & -0.00132 & \\
\hline & & & $(0.00975)$ & \\
\hline \multirow[t]{2}{*}{ L2.Icounaverage } & & & $0.0265^{* * *}$ & \\
\hline & & & $(0.00852)$ & \\
\hline \multirow[t]{2}{*}{ L3.Icounaverage } & & & 0.00452 & \\
\hline & & & $(0.0106)$ & \\
\hline \multirow[t]{2}{*}{ L.Iregaverage } & & & & -0.000732 \\
\hline & & & & $(0.00965)$ \\
\hline \multirow[t]{2}{*}{ L2.Iregaverage } & & & & $0.0341^{* * *}$ \\
\hline & & & & $(0.00931)$ \\
\hline \multirow[t]{2}{*}{ L3.Iregaverage } & & & & 0.00450 \\
\hline & & & & $(0.0101)$ \\
\hline $\mathrm{N}$ & 956 & 734 & 734 & 734 \\
\hline $\mathrm{R} 2$ & & & & \\
\hline
\end{tabular}

aStandard errors in parentheses, ${ }^{*} p<0.1,{ }^{* *} p<0.05,{ }^{* * *} p<0.01$ 